EESTI NSV TEADUSTE AKADEEMIA TOIMETISED. V KOIDE

BIOLOOGISINE SEERIA. 1956, NR. 2

- ИЗВЕСТИЯ АКАДЕМИИ НАУК ЭСТОНСКОЙ ССР. ТОМ V

СЕРИЯ БИОЛОГИЧЕСКАЯ. 1956, №2 2

\title{
ИССЛЕДОВАНИЕ ХИМИЧЕСКОГО СОСТАВА \\ И АНТИБАКТЕРИАЛЬНЫХ СВОЙСТВ ПАРОВЫХ ДЕСТИЛЛАТОВ И ВОДНЫХ ЭКСТРАКТОВ ХААПСАЛУСКОЙ ЛЕЧЕБНОЙ ГРЯЗИ
}

\author{
Н. А. ДЕРБЕНЦЕВА,
}

кандидат химических наук

\section{В. А. ФРАДКИН}

До недавнего времени бальнеологи и клиницисты придавали основное значение в механизме комплексного действия лечебных грязей их физическим и химическим свойствам. Дальнейшие же исследования (Б. Л. Исаченко $\left({ }^{3}\right)$ и др.) позволили накопить данные о роли микроорганизмов, принимающих активное участие в процессе формирования свойств и особенностей водоемов. А. Л. Шинкаренко и О. Ю. Волкова $\left({ }^{1},{ }^{7}\right)$ обнаружили в лечебных грязях Тамбуканского озера антибиотические вещества типа пенициллина и грамицидина и доказали их бактерицидное действие на ряд микроорганизмов (стрептококк, стафилококк, кишечная палочка и др.).

Особый интерес для изучения представляет процесс воздействия на организм жидкой фазы лечебных грязей, полученной в виде грязевых растворов, отжимов и водных экстрактов, содержащих в себе растворенные минеральные соли и органические вещества. Исследуя экстракты и отгоны из лиманной грязи, В. П. Филатов, В. А. Бибер, Н. С. Боголюбова $\left({ }^{6}\right)$ и др. обнаружили в их составе химические вещества типа биогенных стимуляторов, попадающие в грязь из отмирающего фито и зоопланктона. В результате этого отгоны и экстракты из лиманной грязи нашли широкое применение при лечении глазных болезней.

В настоящее время клиника располагает уже такими апробированными средствами, как пелоидин, полученный M. М. Приселковым ( $\left.{ }^{5}\right)$ и пелоидестиллат, приготовленный по методу В. П. Филатова. Первый из них изменяет тинкториальные свойства микробной клетки, повышает ее фагоцитабельность, снижает инвазивные свойства микроорганизмов, а также, - по данным А. Е. Лейбензона $\left({ }^{4}\right)$, стимулирует физиологическую систему и усиливает репаративные процессы организма. Клиника показала значительную эффективность пелоидина при дизентерии, гриппе, воспалительных и нагноительных процессах. Что же касается пелоидестиллата, то помимо лечения глазных болезней он применяется при терапии бронхиальной астмы и артритов различной этиологии.

Учитывая вышеприведенные данные, а также то, что на территории Эстонской ССР расположены многочисленные мощные залегания грязей, часть из которых используется в лечебных целях (грязь Хаапсалуского залива и Курессаареская грязь), и было предпринято настоящее исследование. 
В результате изучения химического состава органического вещества эстонских лечебных грязей и их бактерицидных свойств, проведенных Н. А. Дербенцевой и А. М. Ховановой $\left({ }^{2}\right)$, был установлен химический состав основных групп органического вещества Хаапсалуской лечебной грязи, наличие обильной микрофлоры и бактерицидного действия нативной грязи в целом и особенно ее компонентов, извлекаемых органическими растворителями.

Задача настоящей работы заключалась в изучении химического состава и бактерицидных свойств жидкой фазы эстонской грязи с целью использования полученных препаратов в медицинской практике.

Были получены паровые дестиллаты и водные экстракты Хаапсалуской лечебной грязи и исследованы их физико-химические данные, кислотный состав и бактерицидные свойства. Лечебная грязь исследовалась в нативной форме с содержанием воды $73,78 \%$ и в подсушенном виде, с содержанием воды $8,06 \%$. Такая дифференцировка была произведена с целью выяснения влияния подсушивания грязи на качество указанных препаратов.

Получение паровых дестиллатов. Паровые дестиллаты грязей были получены следующим образом: нативная грязь в количестве около $200 \mathrm{r}$ подкислялась $15 \mathrm{~cm}^{3} 25 \%$ серной кислоты для выделения летучих кислот и перегонялась с водяным паром. Подсушенная при $30^{\circ} \mathrm{C}$ грязь в количестве около 50 г заливалась равным количеством дестиллированной воды и непосредственно перед перегонкой подкислялась тем же количеством $25 \%$ серной кислоты. В обоих случаях перегонка с водяным паром продолжалась $2-2,5$ часа. Объем дестиллатов составлял в среднем около $300 \mathrm{~cm}^{3}$. В полученных препаратах, представляющих собой бесцветную прозрачную жидкость, определялись следующие химические показатели: общая кислотность (титрованием $0,01^{\prime} N$ натриевой щелочью по фенолфталеину), окисляемость в мг перманганата, иодное число по методу Моргашеса, сероводород по Кашинскому, общий азот по Кьельдалю и удельный вес. Результаты представлены в таблице 1.

\section{Основные показатели паровых дестиллатов, полученных из Хаапсалуской лечебной грязи *}

\begin{tabular}{|c|c|c|c|c|c|c|c|c|c|}
\hline \multirow[b]{2}{*}{$\begin{array}{l}\text { Наименование } \\
\text { образца грязи }\end{array}$} & \multirow{2}{*}{ 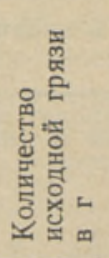 } & \multirow[b]{2}{*}{ 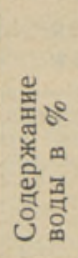 } & \multirow{2}{*}{ 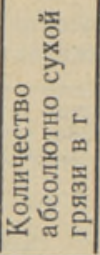 } & \multicolumn{6}{|c|}{$\begin{array}{c}\text { Наименование показателей паровых } \\
\text { дестиллатов }\end{array}$} \\
\hline & & & & 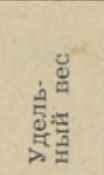 & 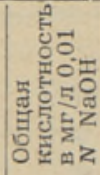 & 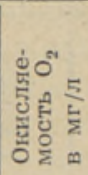 & 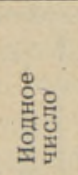 & 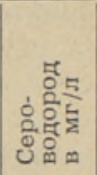 & $\begin{array}{l}\frac{5}{5} \\
\text { 要 }\end{array}$ \\
\hline Нативная грязь & 181,30 & 73,78 & 47,54 & 0,9997 & 8,00 & 10,30 & 8,80 & 2,34 & 31,24 \\
\hline $\begin{array}{c}\text { Подсушенная } \\
\text { грязь }\end{array}$ & 50,78 & 8,06 & 46,71 & 0,9998 & 6,50 & 7,60 & 4,99 & 2,79 & 31,24 \\
\hline
\end{tabular}

* В таблицах представлены средние данные четырех и пяти параллельных определений. 
Получение водных экстрактов. При получении водных экстрактов ив нативной и высушенной грязи последняя настаивалась при периодическом взбалтывании в течение двух суток с дестиллированной водой, взятой в соотношении с навеской сырой грязи $(1: 1)$ и сухой грязи $(1: 10)$. Затем водная часть отделялась фильтрованием.

В прозрачных экстрактах интенсивно желтого цвета определялись следующие химические показатели: общая кислотность (титрованием $0,01 N$ натриевой щелочью по фенолфталеину), окисляемость, иодное число, сероводород, общий азот и удельный вес, Результаты приведены в таблице 2.

Таблица 2

Основные показатели водных әкстрактов Хаапсалуской лечебной грязи

\begin{tabular}{|c|c|c|c|c|c|c|c|c|c|c|}
\hline \multirow[b]{2}{*}{$\begin{array}{l}\text { Наименование } \\
\text { образца грязи }\end{array}$} & \multirow{2}{*}{ 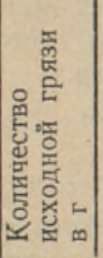 } & \multirow{2}{*}{ 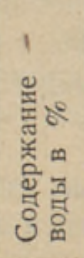 } & \multirow{2}{*}{ 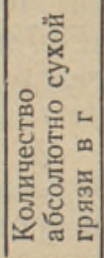 } & \multicolumn{7}{|c|}{$\begin{array}{c}\text { Наименование показателей во } \\
\text { экстрактов }\end{array}$} \\
\hline & & & & 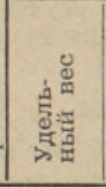 & 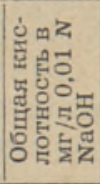 & 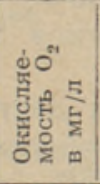 & 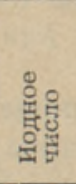 & 员5 & $\begin{array}{l}5 \\
50 \\
0 \\
40 \\
40\end{array}$ & 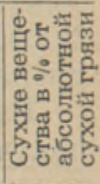 \\
\hline Нативная грязь & 191,92 & 73,78 & 50,32 & 1,0022 & 4,00 & 24,82 & 3,39 & 2,80 & 78,10 & 2,50 \\
\hline $\begin{array}{c}\text { Подсушенная } \\
\text { грязь }\end{array}$ & 50,00 & 8,06 & 46,00 & 1,0038 & 6,00 & 39,85 & 5,75 & 1,87 & 72,28 & 1,74 \\
\hline
\end{tabular}

Определение органических, в том числе летучих, кислот в паровых дестиллатах и водных экстрактах. Исходя из литературных указаний о биологической активности многих органических кислот жирного и ароматического ряда, мы провели исследования по определению содержания органических, в том числе летучих, кислот в паровых дестиллатах и водных экстрактах, полученных из Хаапсалуской лечебной грязи.

Для выделения свободных летучих кислот водные экстракты подкислялись серной кислотой и перегонялись с водяным паром. В полученных препаратах определялись: общая кислотность в пересчете на уксусную кислоту, муравьиная кислота - путем разрушения ее хромовой смесью,

Таблица 3

Содержание летучих и нелетучих органических кислот в паровых дестиллатах и водных экстрактах

\begin{tabular}{|c|c|c|c|c|c|c|c|}
\hline \multirow[b]{2}{*}{ Наименование } & \multirow[b]{2}{*}{ 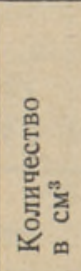 } & \multirow{2}{*}{ 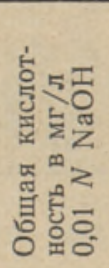 } & \multicolumn{4}{|c|}{$\begin{array}{c}\text { Количество летучнх кислот в \% от } \\
\text { абсолютно сухой грязи в пересчете } \\
\text { на уксусную кислоту }\end{array}$} & \multirow{2}{*}{ 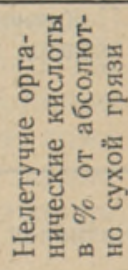 } \\
\hline & & & 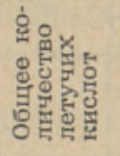 & 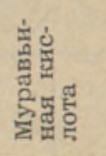 & 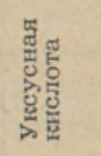 & 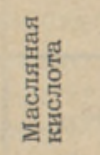 & \\
\hline $\begin{array}{l}\text { Паровой } \\
\text { дестиллат }\end{array}$ & 295 & 8,0 & 0,028 & 0,0013 & 0,0124 & 0,0143 & 0,020 \\
\hline $\begin{array}{c}\text { Водный } \\
\text { эКстракт }\end{array}$ & 300 & 5,5 & 0,0797 & 0,0021 & 0,0172 & 0,0605 & 0,026 \\
\hline
\end{tabular}


масляная кислота по Файльману и уксусная кислота по разности. Из не перегоняющегося остатка органические кислоты извлекались серным эфиром и определялись суммарно титрованием $0,01 N$ натриевой щелочью по фенолфталеину. Результаты представлены в таблице 3 .

Исследование паровых дестиллатов и водных экстрактов лечебной грязи с точки зрения их биологической активности. Биологическая активность водных экстрактов и паровых дестиллатов лечебной грязи проверялась на их способности стимулировать подъемную силу дрожжей. Әтот опыт дает возможность в короткий срок сделать правильный ориентировочный вывод.

Влияние приготовленных препаратов на подъемную силу дрожжей определялось по кольцу, оставленному поднявшимся тестом на стенках мерного цилиндра. К точно взвешенному количеству дрожжевого теста, помещенного в мерные цилиндры, прибавлялось по $2 \mathrm{~cm}^{3}$ испытуемого раствора. Цилиндры с содержимым помещались на одни сутки в термостат при $36-37^{\circ} \mathrm{C}$. Через $3-4$ часа поднявшееся тесто начинало оседать, оставляя на стенках цилиндра кольцо, по которому можно было учесть максимальное увеличение подъема и дать сравнительную оценку подъемной силы различных вытяжек. Для контроля служили дестиллированная вода и физиологический раствор. В каждой исследуемой вытяжке предварительно определялась величина сухого остатка. В отдельных опытах экстракты разводились в 2,5 и 3,5 раза. Результаты четырех параллельных определений приведены в таблице 4.

Таблица 4

Влияние' полученных препаратов на подъемную силу дрожжей

\begin{tabular}{|c|c|c|c|c|c|c|c|c|c|c|c|}
\hline \multirow{4}{*}{$\begin{array}{l}\text { Биологиче- } \\
\text { ская антивность }\end{array}$} & \multicolumn{2}{|c|}{ Контроль } & \multirow{4}{*}{ 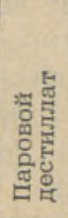 } & \multicolumn{8}{|c|}{ Водные экстракты } \\
\hline & \multirow{3}{*}{ 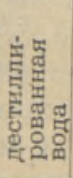 } & \multirow{3}{*}{ 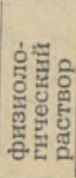 } & & & A & \multirow{2}{*}{\multicolumn{2}{|c|}{ 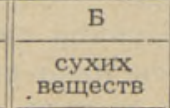 }} & \multirow{2}{*}{\multicolumn{2}{|c|}{$\frac{\text { B }}{\begin{array}{c}\text { сухих } \\
\text { веществ }\end{array}}$}} & \multirow{2}{*}{\multicolumn{2}{|c|}{ 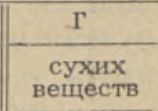 }} \\
\hline & & & & \multicolumn{2}{|c|}{$\begin{array}{c}\text { сухих } \\
\text { веществ }\end{array}$} & & & & & & \\
\hline & & & & $2,9 \%$ & $0,31 \%$ & $1,95 \%$ & $0,8 \%$ & $1,39 \%$ & $0,69 \%$ & $1,74 \%$ & $0,87 \%$ \\
\hline $\begin{array}{c}\text { Максимальная подъем- } \\
\text { ная сила дрожжей, } \\
\text { выраженная в см³ }\end{array}$ & 41,5 & 40,0 & 41,3 & 40,0 & 52,0 & 53,17 & 45,0 & 55,0 & 45,0 & 46,3 & 42,0 \\
\hline
\end{tabular}

* Экстракты А и Б получены из подсушенной грязи, экстракты В и $Г$ - из нативной грязи с предварительным охлаждением (в течение 14 суток при $+20^{\circ} \mathrm{C}$ ).

Изучение бактерицидного действия паровых дестиллатов и водных экстрактов Хаапсалуской лечебной грязи. Антибактериальное действие полученных паровых дестиллатов и водных экстрактов изучалось в отношении возбудителя дизентерии (тип Flexner), кишечной палочки и белого стафилококка, выделенного из раны больного. Особое внимание было уделено подбору методики. Была апробирована нижеследующая методика, являющаяся, на наш взгляд, нанболее объективной и точной.

Суточный слив культуры разводился в физиологическом растворе по стандарту до 500 млн. микробных тел в 1 мл. Далее разведенная по стандарту взвесь разводилась еще в 100 раз, после чего культура в объеме 0,1 мл (500 000 микробных тел) вносилась в пробирки. Для исследования полученных препаратов в отношении каждой из трех культур брался следующий ряд пробирок: 1) 4 мл бульона + 1 мл препарата, 2) 2,5 мл бульона $+2,5$ мл препарата, 3) 5 мл препарата, 4) 5 мл бульона, 5) 5 мл физиологического раствора, если изучался экстракт, или 5 мл дестиллированной воды, если изучался паровой дестиллат. Затем все пробирки ставились в термостат при $37^{\circ}$. Спустя 24 часа они вынимались из термо- 
стата и из каждой пробирки делались разведения от 1:10 до 1: 100000. Из 3, 4 и 5 разведений брался микропипеткой материал (в объеме 0,1 мл) и вносился на поверхность мясопептонного агара, разлитого в чашки Петри, с последующим растиранием по поверхности чашки. Посевы термостатировались в течение суток при $37^{\circ}$, после чего производился подсчет выросших колоний.

Из полученных данных выводилось среднее арифметическое число, которое и характеризовало степень антибактериального действия препарата на ту или иную культуру. Для исследований были взяты паровые дестиллаты и водные экстракты, изучавшиеся одновременно с точки зрения химического состава и биологической активности. Полученные в каждой из обеих групп результаты оказались настолько однородными, что представилось возможным выразить в виде рисунка антибактериальное действие лишь двух препаратов: парового дестиллата № 4 и водного экстракта № 7 (рис. 1 и 2).

\section{Обсуждение результатов}

Подводя общие итоги проведенной работы, следует отметить некоторую зависимость между количественным составом полученных препаратов и состоянием исходной грязи.

Паровые дестиллаты, полученные из нативной грязи, имели бо́льшие величины кислотности, окисляемости и иодного числа, чем дестиллаты из подсушенной грязи. Содержание сероводорода и общего азота в обоих образцах примерно одинаково. В случае водных экстрактов величина общей кислотности, окисляемости и иодного числа выше у препаратов, полученных из подсушенной грязи; содержание же сероводорода и общего азота, наоборот, несколько выше у экстрактов из нативной грязи. Различий в качественном составе препаратов, полученных из нативной и подсушенной грязи, установить не удалось. Отсюда можно сделать вывод, что подсушивание грязи не оказывает существенното влияния на химический состав полученных препаратов. Бо́льшая величина окисляемости препаратов, которая у водных экстрактов составляет 25-40 мг/л кислорода; свидетельствует о наличии в них минеральных веществ и веществ растительного и животного происхождения. Әто подтверждается количеством сухого остатка в экстрактах, которое колеблется в пределах 1,8 $2,5 \%$, достигая в отдельных случаях $3 \%$. Иодные числа, характеризующие количество непредельных кислот, составляют в дестиллатах величину от 5 до 9 г/л, а в соответствующих экстрактах от 3,4 до 5,7 г/л, что хорошо согласуется с величиной общей кислотности.

При определении летучих кислот было установлено присутствие муравьиной, масляной и уксусной кислот, а также небольших количеств нелетучих органических кислот (молочной). При этом в водных экстрактах летучих кислот оказалось больше, чем в паровых дестиллатах, что свидетельствует о наличии в лечебной грязи водорастворимых солей этих кислот.

Исследование биологической активности грязевых экстрактов и дестиллатов выявило их стимулирующее действие на размножение сахаромицетов или дрожжевых грибков. Более активными оказались, по нашим данным, водные экстракты, содержащие бо́льшее количество летучих кислот, чем паровые дестиллаты. Это обстоятельство служит подтверждением биологической активности ряда органических кислот.

Разведение экстрактов водой, уменьшающее содержание в них сухих веществ, предпринятое с целью увеличения их биологической активности, 
Cocmab сред, на komoрые засевалась изучавиаяcя мukpoфnopa:

5 мก. ठульонС

11. 5 мл. физиопогичесkого pacmBopa

पIII 4 мп. бупьона и 1 мп. Водного зkсmpakma 2,5 мл. бульона и 2,5 мл. Водного эkcmpakma

5 мก. Водного 3kcmpakmo

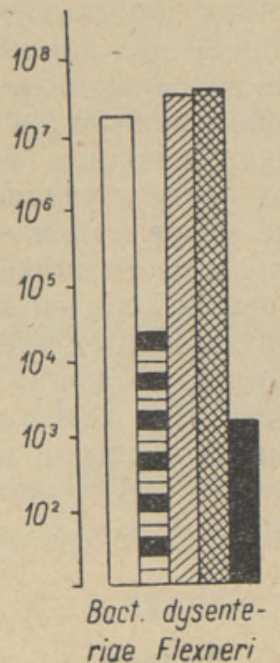

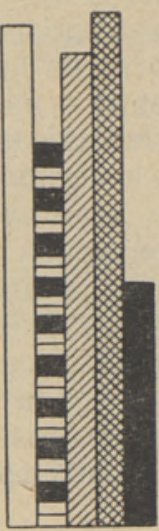

Bact. coli

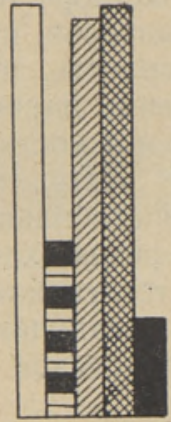

Staphylococcus

albus

Рис. 1. Показатели антибактериального действия водного экстракта № 7.

Cocmob cped, no komoрые засевапась изучавшаяcR мukрофлоро :

5 мл. бульоно

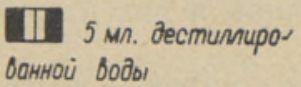

पIIIA 4 мп. оулоона ч 1 мn. napobozo decmunname 2,5 мл. бульона и 2,5 Mn. nopoboro decmunnama

5 мn. паровоro decmunnama

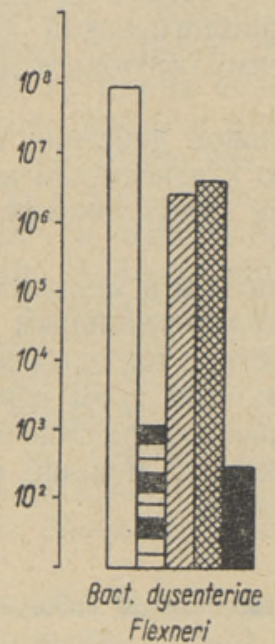

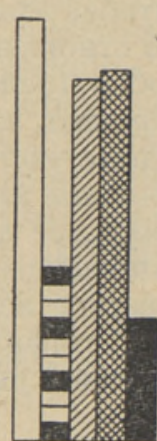

Bact. coli

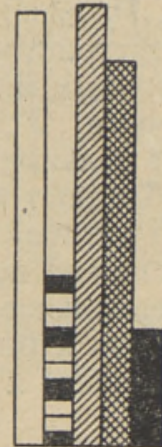

Staphylococcus albus

Рис. 2. Показатели антибактериального действия парового дестиллата № 4.

не дало в наших опытах закономерных результатов. То же можно сказать и о предварительной выдержке нативной грязи (перед получением экстрактов) при низких температурах без доступа света. Поэтому разбавление экстрактов и дестиллатов водой для установления соответствующих тестов едва ли является необходимым.

Как видно из рис. 1 и 2, паровые дестиллаты и водные экстракты ока- 
зывают антибактериальное действие лишь в неразведенном виде. Размножение же микроорганизмов в смеси, содержащей $50 \%$ питательной среды и $50 \%$ препарата, во всех случаях происходит без какой-либо задержки. Это легко определяется путем сравнения данных, полученных в этих условиях, с ростом микрофлоры на цельной питательной среде. Сопоставление показателей роста на цельном водном экстракте и на физиологическом растворе говорит о наличии в водном экстракте каких-то добавочных факторов, препятствующих росту изучавшихся культур. Эта же закономерность, хотя и несколько менее выраженная, наблюдается также в отношении паровых дестиллатов и дестиллированной воды.

Возможность получения больших количеств паровых дестиллатов и водных экстрактов из Хаапсалуской лечебной грязи, водорастворимость и термостабильность компонентов, входящих в их состав, а также общность физико-химических свойств этих компонентов с уже известными соответствующими препаратами из иловых и торфяных грязей дают основание предполагать возможность клинического использования жидкой фазы эстонской лечебной грязи.

\section{Выводы}

1. Изучен общий химический состав паровых дестиллатов и водных экстрактов Хаапсалуской лечебной грязи.

Установлено: а) наличие в них минеральных и органических веществ, сероводорода, азотистых соединений;

б) определены летучие и нелетучие органические кислоты. Установле но присутствие муравьиной, масляной и уксусной кислот, а также небольшого количества нелетучих органических кислот.

2. Обнаружено наличие биологической активности у некоторых препаратов, выявившееся в стимулирующем действии их на размножение дрожжевых грибков.

3. Изучено антибактериальное действие паровых дестиллатов и водных экстрактов по отношению к некоторым видам патогенных и условнопатогенных микробов (белому стафилококку, кишечной и дизентерийной палочкам). Установлено, что:

а) цельные водные экстракты и в меньшей степени паровые дестиллаты обладают известным антибактериальным действием;

б) антибактериальное действие паровых дестиллатов выражено в равной степени по отношению ко всем трем изучавшимся культурам. Антибактериальное действие водных экстрактов более всего выражено по отношению к белому стафилококку, меньше к возбудителю дизентерии и еще меньше к кишечной палочке.

Ннститут экспериментальной и клинической медицины Академии наук Эстонской ССР
Поступила в редакцию 2 VI 1955

\section{ЛИТЕРАТУРА}

1. О. Ю. Волков а и А. Л. Ш инк ар енко, Труды Государственного бальнеологического института на Қавказских минеральных водах, тт. XXIV-XXV, 1946.

2. Н. А. Д ер бенцев а и А. М. Хов ан ов а, Известия АН ЭССР, т. IV, № 1, 1955.

3. Б. Л. И с а чен к о, Избранные труды, т. 2, 1951.

4. А. Е. Л й бен з он, Вопросы курортологии, № 5, 1940, стр. 9-10. 
5. М. М. При селков, Журнал микробиологии, эпидемиологии и иммунобиологии, № 5, 1953, стр. 60 .

6. В. Л. Филатов, В. А. Бибер, Н. С. Богомолова, Сборник жТканевая терапия», 1953 г., стр. $52-58$.

7. А. Л. Шинка ен но, Труды Государственного бальнеологического института на Кавказских минеральных водах, тт. XXVI-XXVII, 1948.

\title{
HAAPSALU RAVIMUDA AURUDESTILLAATIDE JA VESIEKSTRAK- TIDE KEEMILISE KOOSTISE NING BAKTERITSIIDSE TOIME UURIMISEST
}

\author{
N. DERBENTSEVA,
}

keemiateaduste kandidaat

V. FRADKIN

Resümee

Kuni viimase ajani omistasid balneoloogid ja klinitsistid ravimudade füüsikalistele ning keemilistele omadustele väga suurt tähelepanu. Järgnevad uurimised vôimaldasid selgitada mikroorganismide tähtsat osa veekogude omaduste ja iseärasuste kujunemisel.

Lähtudes eksperimentaalse ja kliinilise meditsiini vajadustest, pakub erilist huvi ravimudade vedela faasi, s. o. ravimudade lahuste ja vesiekstraktide bioloogiliste omaduste uurimine. Eesti territooriumil paikneb arvukalt võimsaid mudalademeid, milledest osa kasutatakse ravi otstarbeks. Meie ülesandeks oli Haapsalu ravimuda vedelast faasist saadud destillaatide ja vesiekstraktide keemilise koostise ning bakteritsiidse toime uurimine, et nendest valmistatud preparaate kasutada meditsiinilises praktikas.

Saadud aurudestillaatide ja vesiekstraktide keemilise koostise uurimisel tehti nendes kindlaks mineraal- ja orgaaniliste ainete, väävelvesiniku ning lämmastikuühendite olemasolu. Määrati lenduvad ja lendumatud orgaanilised happed. Tehti kindlaks sipelghappe, vōihappe ning äädikhappe olemasolu, vähesel hulgal ka lendumatute orgaaniliste hapete olemasolu.

Aviastati mõnede preparaatide bioloogiline aktiivsus, mis väljendub nende stimuleerivas toimes pärmiseente paljunemisele.

Uuriti aurudestillaatide ja vesiekstraktide antibakteriaalset toimet mõnede patogeensete ja fakultatiivselt patogeensete mikroobide liikidele (valgele stafülokokile, coli- ja düsenteeria-bakterile).

Tehti kindlaks, et

a) lahjendamata vesiekstraktid ja vähemal määral ka aurudestillaadid on teatava antibakteriaalse toimega;

b) aurudestillaatide antibakteriaalne toime on võrdne kõigi kolme uuritud kultuuriga. Vesiekstraktide antibakteriaalne toime väljendub kõige enam valge stafülokoki suhtes, vähem düsenteeria-bakteri ja veel vähem coli-bakteri suhtes. 


\section{L'EXAMEN DE LA COMPOSITION CHIMIQUE ET DES FACULTÉS ANTIBACTERIENNES DES DESTILLATS PAR VAPEUR ET DES EXTRAITS AQUEUX DES BOUES MÉDICALES DU GOLFE DE HAAPSALU}

\section{N. DERBENTSEVA \\ V. FRADKIN}

Résumé

Il a été préparé des extraits des parties liquides des boues médicales du golfe de Hapsal et étudié leur nature chimique et leur action antibactérienne sur le Staphylococcus albus, Bacterium coli et Bacterium dysenteriae Flexneri.

On a découvert la présence des substances minérales et organiques, de l'hydrogène sulfuré et des composés d'azote.

On a aussi établi l'activité biologique de certains extraits, qui se manifeste par la stimulation de la reproduction des Saccharomycetes.

Institut de Médecine Expérimentale et Clinique de l'Académie des Sciences de RSS d'Estonie
Reçu à la rédaction le 2. juin 1956 